\title{
Comparative Analyses of Height Growth Velocities of School Boys in South Korea and Japan in the Past 50 Years
}

\author{
Hiroshi Mori \\ Senshu University, Tokyo, Japan \\ Email: hymori@isc.senshu-u.ac.jp
}

How to cite this paper: Mori, H. (2020) Comparative Analyses of Height Growth Velocities of School Boys in South Korea and Japan in the Past 50 Years. Food and Nutrition Sciences, 11, 659-668. https://doi.org/10.4236/fns.2020.117047

Received: June 8, 2020

Accepted: July 7, 2020

Published: July 10, 2020

Copyright $\odot 2020$ by author(s) and Scientific Research Publishing Inc. This work is licensed under the Creative Commons Attribution International License (CC BY 4.0).

http://creativecommons.org/licenses/by/4.0/

\section{(c) (i) Open Access}

\begin{abstract}
The paper compares the height growth velocities of male schoolchildren in South Korea and Japan over the period 1961-2018. Growth in height was measured with the same birth cohorts, not by comparing mean height of ascending ages in the same year. Starting from a lower economic base and mean height in the 1960s, high school males aged 17 in South Korea became $3 \mathrm{~cm}$ taller in mean height than their Japanese peers in the mid-2000s versus 2 - 3 $\mathrm{cm}$ shorter in the 1960s through 1970s. Children in Japan ceased to grow taller by the end of the 1980s, not because they quit taking more animal-sourced foods, meat and milk, but because they had drastically steered away from fruit and vegetables in their diets since the end of the 1970s. Having largely converged economically with Japan, South Korean children ceased to grow any taller in the mid-2000s. More importantly, it was discovered in this study that successive cohorts in South Korea started to fall gradually but steadily in height growth velocity from $1^{\text {st }}$ graders in middle school, aged 12 years to $3^{\text {rd }}$ graders in high school, and aged 17 years, to be once again $3 \mathrm{~cm}$ below their Japanese peers in the early-2010s. Analysis of Korea Household Expenditure Surveys classified by age groups of household head, decomposed by the author, revealed that children under 20 years of age in South Korea began to steer away from fruit and, particularly, vegetables in their at-home consumption in the mid-1990s, to average only $15 \%$ of the level of older adults in their 50s in the mid-2010s. These results lend supports to the importance of fruit and vegetables as determinants in height and its growth velocities in two genetically similar nations over time and stages of economic growth.
\end{abstract}

\section{Keywords}

Height, School Boys, Growth Velocities, Birth Cohort, South Korea, Japan, Vegetables and Fruit 


\section{Introduction}

In the arena of economic history, human height has been widely held to represent standards of living in the society [1]. Comparing mean height of high school seniors, Japanese were a few cm taller than South Koreans in the 1960s through the early-1980s but overtaken by the latter by a few $\mathrm{cm}$ in the mid-2000s (Figure 1). In the beginning of the 1990s, Japan's economy suddenly fell into a decades' long recession, with normal growth resuming only in the mid-2010s, whereas South Korea maintained rapid and steady economic progress over the same period.

Thus, per capita disparity in net GDP between the two countries has sharply narrowed during the past three decades. When purchasing power parity is taken into consideration, South Koreans may be enjoying almost the same standard of living as Japanese at the end of the 2010s. No doubts remain, but South Korea was still considerably behind Japan in respect of living standards in the early-2000s [2]. The statistical fact that Korean teens were a few $\mathrm{cm}$ taller than their Japanese peers in the mid-2000s could be attributed to alleged ethnic difference [3]. On the other hand, for decades South Koreans' diets, differed from those of the Japanese: appreciably more rice and vegetables; and less milk than in Japan, with nearly the same amount of animal meat only in recent years [4]. As a food economist, the author has attempted to explore the reversed differences in child height between the two countries in the past half century, with the tacit assumption of similarity of the two nations in ethnic endowments in stature [5].

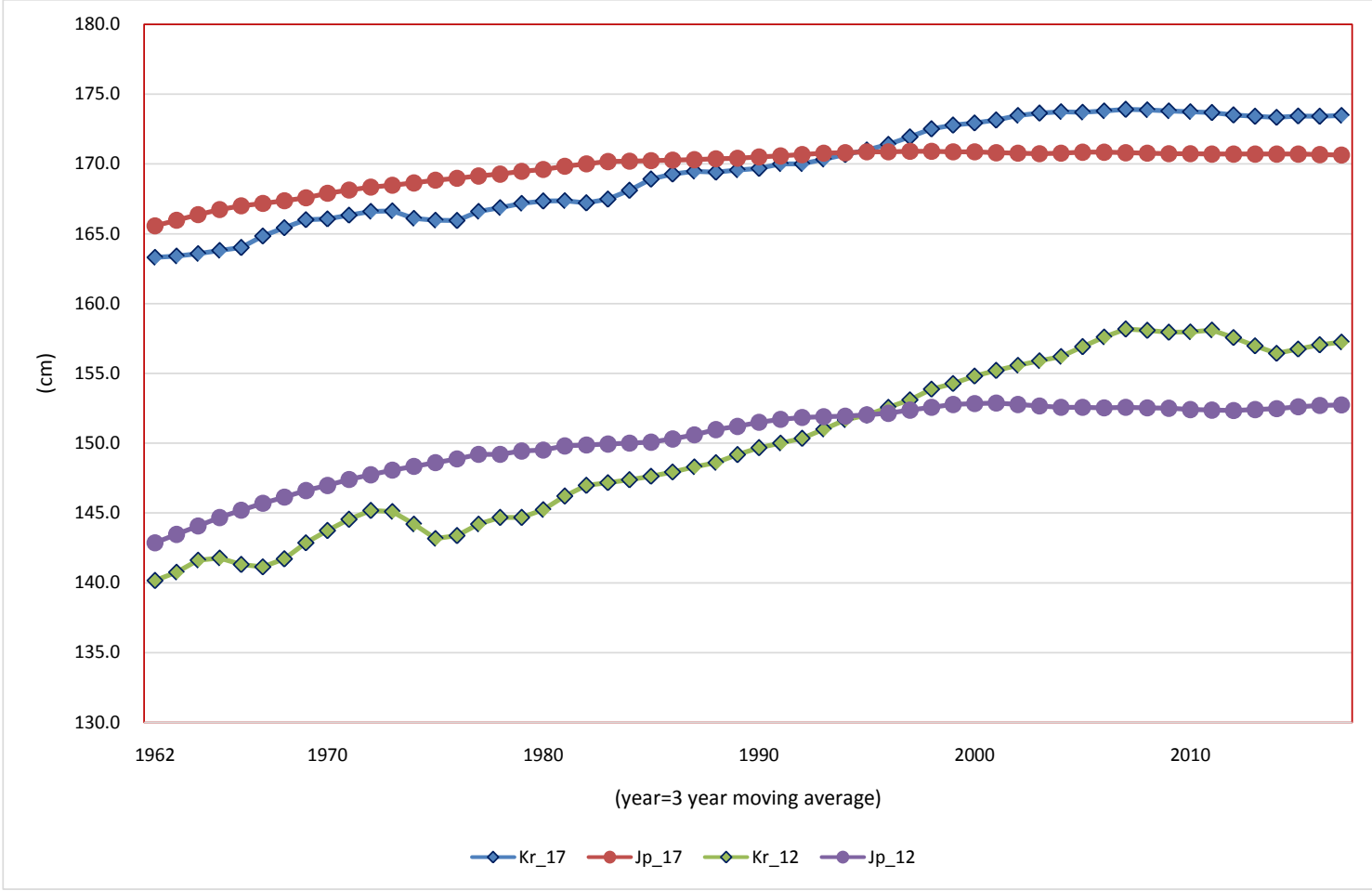

Figure 1. Changes in mean height of boys at 12 and 17 years of age, South Korea and Japan, 1962 to 2017. 


\section{Basic Analytical Frameworks}

Korea was under Japan's colonization before the end of WW II and then divided into two countries, the Republic of Korea (South Korea) and Democratic People's Republic of Korea (North Korea). Due to the countywide devastations by Korean War (1950-53), South Korea's per capita GDP was US\$158 in 1960 and US\$279 in 1970. It rose, however, rapidly to US\$1704 in 1980, and US\$6516 in 1990. In comparison, Japan's per capita GDP was US\$479 in 1960 and US\$25,389 in 1990 [2]. Food consumption in South Korea improved appreciably both in quantity and quality over the period. Per capita caloric intake, excluding alcoholic beverages, increased from $2218 \mathrm{kcal} /$ day in 1962 to 2390 and $2853 \mathrm{kcal} /$ day, in 1975 and 1990, respectively. Per capita caloric supply from animal sourced products, meat, eggs, milk and fish, increased from $78 \mathrm{kcal}$ in 1962 to 141 and $337 \mathrm{kcal} /$ day over the same period [4] [6].

In most anthropometric analyses of human height, including our studies, the magnitude of stature has been regressed against the level of current living standards across the nations and or over the chosen periods of time [7] [8] [9] [10] [11]. In the arena of human biology, the importance of earlier years of life has been emphasized in common [12] [13]. Cole and Mori (2017) concluded: most of the height increment seen in adults had already accrued by the age of 1.5 years [14]. Should it be the case, any foods either in quantity or quality, taken in adolescence, for example, would not result in significant height increment in future adult. The author questions this connotation.

Girls, under normal circumstances, do not grow appreciably in height after the age of 15 years. Any improvements in "inputs to health" after this critical age would not result in sizable increases in height but, interestingly, when they give birth to their babies after 10 to 15 years, their children would be bigger in stature and grow taller in height, than otherwise. It has not been made empirically determined what betterment in food intake at what stage of life would result in meaningful increases in future adult height. This merits further examination particularly by the researchers in the bio-medical sciences.

The author has attempted to clarify empirically which or what changes in food consumption may have resulted in what changes in child growth by age groups in Japan and South Korea, nations with supposedly similar ethnic traits, over the past half century. Child height by age in Japan has been officially provided every year by National Nutrition Surveys conducted by the Ministry of Health and Welfare since 1948 [15] and also by School Health Examination Surveys conducted by the Ministry of Education since the early $20^{\text {th }}$ century [16]. The data sources are similar in South Korea but National Nutrition Surveys were first conducted on intensive scale only in 1998 , followed by the $2^{\text {nd }}$ in 2001 , then $3^{\text {rd }}$ in 2005 in South Korea [17], whereas School Health Examination Surveys have been conducted consistently every year since 1961, results of which have been officially published in the Statistical Year Books/Annals of Education, Department of Education [18]. 
School Health Examination Surveys are the major data sources for child height in both South Korea and Japan in this study. School Surveys cover kindergarten, 5 years of age, through colleges until 1971 in Japan, whereas the Surveys in South Korea cover only primary schools through high schools, 6 to 17 years of age for the entire period. School years start in March in South Korea and April in Japan, respectively and the Surveys are to take place in the first month of the school years. Therefore, $1^{\text {st }}$ year of primary school contains mostly 6 years old children, in both South Korea and Japan. In order to smooth the annual fluctuations, all the data for mean height by age are arranged by 3 year-moving averages: $H_{i t}=$ average $\left(H_{i t-1}: H_{i t+1}\right)$, where $H_{i t}$ denotes mean height of $i$ years of age at year, $t$.

\section{Child Height Growth by Birth Cohorts}

Secular changes in mean height of children in South Korea and Japan in the past half century have been identified by the author and his colleagues, with the utmost concern placed on the comparative analyses of mean height of fully-grown teenagers, i.e., high school seniors, 17 - 18 years of age [4] [19]. In this paper, changes in height growth patterns of school children, from age 6 to 17, mostly boys, will be analyzed and compared between South Korea and Japan since the mid-1960s to the mid-2010s.

A boy born in 1990, for example, aged to 1 year old on his birthday in 1991, 11 years old in 2001, and eventually to 20 years old in 2010, in turn. No one grows instantly from 0 year to 20 years old in the birth year. Everyone grows by one year of age on the birth day in the next year. In order to determine one's growth curves, it is biologically natural to express the mean height of 1 year old in 1991, 11 years old 2001, and 20 years old in 2010, following the same cohort born in 1990, for example. In glancing over selected documents which present child growth curves in South Korea and Japan, one often comes across tables and graphs which provide $3^{\text {rd }}, 50^{\text {th }}$ and $97^{\text {th }}$ percentile values by age ("completed years"), from 6 to 18 years old, for example [20] [21]. In the matured economies, like US, UK, and many European countries, child growth patters from infants through adolescence have been observed to be quite stable during the past half century [22]. South Korea, which has experienced a remarkably rapid economic progress during the past decades, children's growth patterns in height have changed from decade to decade, if not from year to year, as we will see below in this paper.

The most recent cohort, high school seniors, 17 years of age in 2017 (moving average of 2016-2018) were $1^{\text {st }}$ graders in primary school in 2006, 6 years of age. For the earliest period of our investigation, by comparing mean height of primary $1^{\text {st }}$ graders in $1962^{1}$ with middle school $1^{\text {st }}$ graders in 1968 , and eventually high school seniors in 1973, the velocities of growth in height are determined

${ }^{1}$ Official statistics for School Health Surveys, South Korea are available (for the author) only for 1961 fiscal year for the first year, whereas data for the earlier years are available in Japan. 
throughout the school years. Examining the changes in height of the continuous birth cohorts of the last half century in both South Korea and Japan may provide insights into the role of diet in determining biological outcomes: child height growth.

\section{Results and Possible Explanations}

Figure 2 provides comparisons of height growth velocities of school boys from $1^{\text {st }}$ graders in primary school (in 1962) to $1^{\text {st }}$ graders in middle school (in 1968) and from $1^{\text {st }}$ graders in middle school (in 1962) to high school seniors (in 1967) in South Korea and Japan over the past half century ${ }^{2}$. As illustrated by the author in numerous papers in the past few years and briefly mentioned earlier in this paper, South Korean children, both sexes, compared at the ages of maturity, boys at 17 - 18 and girls at $15-16$, were a few $\mathrm{cm}$ shorter in mean height in the 1960s through 1970s, slightly, $1-1.5 \mathrm{~cm}$ shorter in the 1980s than their Japanese peers, the same in the early and mid-1990s and then overtook their Japanese peers in mean height by $2.5-3 \mathrm{~cm}$ toward the mid-2000s, whereas Japanese children ceased to grow any taller at all ages in and around 1990 (Figure 1).

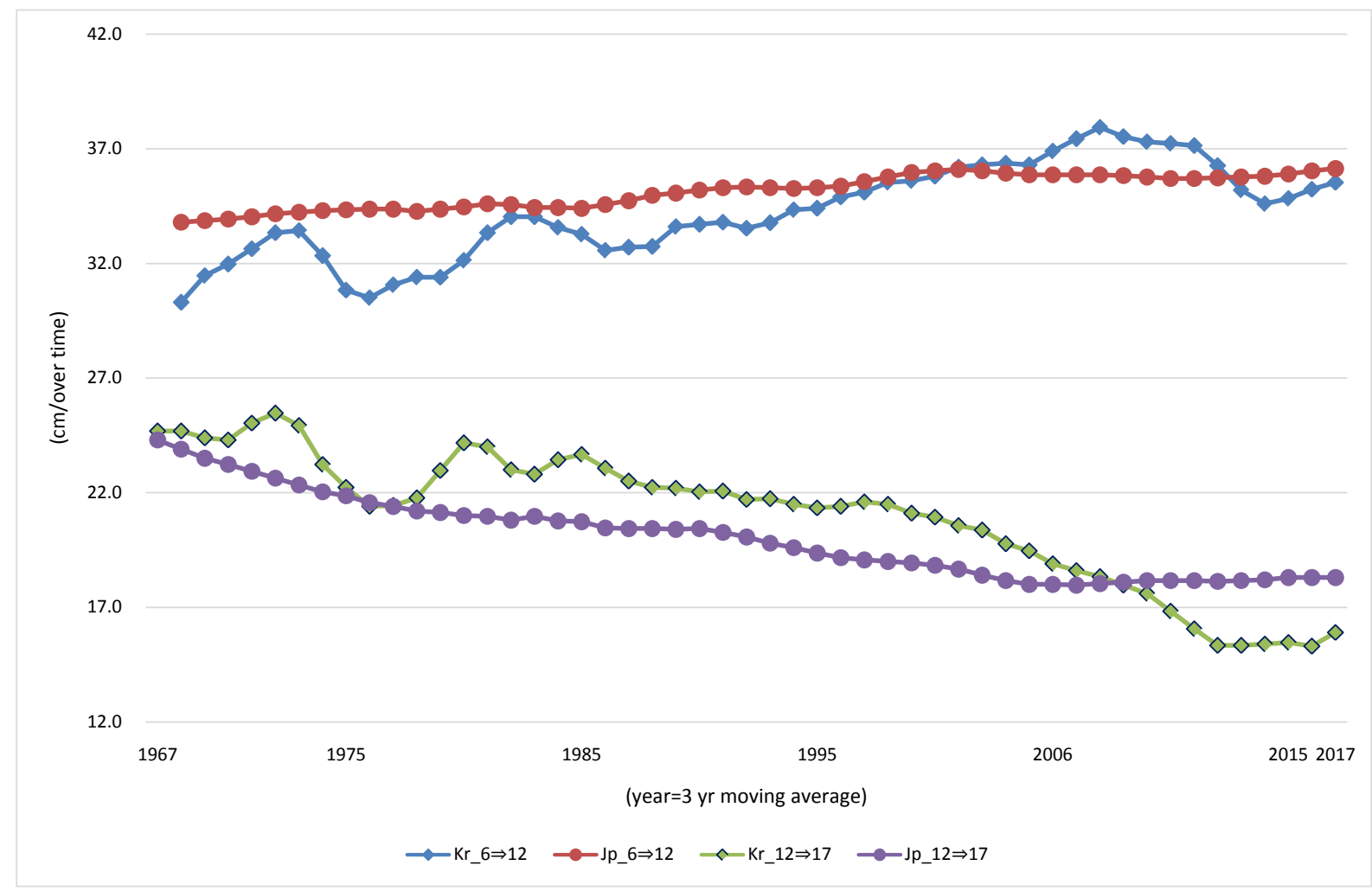

Figure 2. Changes in height growth velocities: 6 yrs to 12 yrs and 12 yrs to 17 yrs, Korean and Japanese school boys, 1966 to 2017 , birth cohorts followed.

${ }^{2}$ Comparing 17 years of age in 1977 with 6 years of age in 1966, for example, might involve non-negligible period effects on top of narrow aging effect from 6 to 17 years, particularly in South Korea a half century ago. In this aspect, comparing high school seniors in 1977 with middle school $1^{\text {st }}$ graders in 1972, for example, might mitigate the age/period complications. 
With respect to growth velocity, the author had expected to find that children in South Korea may have begun overtaking their Japanese peers for the younger ages, say primary school level, already in the 1970s. Against the author's intuition, Korean boys in the primary school ages were appreciably lower in growth velocity than their Japanese peers in the 1960s through mid-1990s and about the same through the mid-2000s and a few $\mathrm{cm}$ faster to 2010 and then fell suddenly below their Japanese peers, although the velocity was clearly upward in trend, as was the case with their Japanese peers. For the older age segment, from middle school $1^{\text {st }}$ graders to high school seniors, South Korean boys were distinctly faster in velocity than their Japanese peers to the late-1990s and began to fall shortly before the year 2000 and then distinctly below their Japanese peers in the 2010s. Despite sizable upward trend in mean height of high school seniors to the mid-2000s, the growth velocity from the first year in middle school to the last year of high school has been falling in trend since the early 1970 s, nearlyas much as $10 \mathrm{~cm}$ in South Korea for the entire period, appreciably greater in the magnitude of velocity fallthan in Japan, where the velocity shows a gradual downward trend since the late-1960s and levelled off after the mid-2000s.

The author has presented his own view that the steady downward trend in growth velocity for the older age group of Japanese school boys from the $1^{\text {st }}$ year in middle school to high school seniors could be attributed to a drastic reduction of per capita at-home consumption of fruit and vegetables by the younger generations since the mid-1970s in Japan [4] [11] [19] [23]. By analyzing Korean Household Expenditure Surveys, classified by age groups of household head, 1990 to 2016 [24], it has become statistically clear that the younger members of South Korean households have steered away from vegetables in their at-home consumption since the late-1990s or so (Tables 1-3). Per capita net supply of vegetables increased appreciably from $131.7 \mathrm{~kg}$ in the early-1990s to $165.2 \mathrm{~kg} /$ year in the early-2000s and then slightly declined to $143.4 \mathrm{~kg} / \mathrm{year}$ in the early-2010s. When per capita at-home consumptionis analyzed by age groups of household members, children under 15 years of age consumed a little more than a half the level of the senior adults in their 50s in the early-1990s but steadily declined to one third the level in the early-2000s and less than one fifth the level in the early-2010s. As a whole population, South Koreans have kept distinctly greater level of vegetable consumption than Japanese, whereas their newer generations have steered away from vegetables in the latest two decades.

School children enrolled in primary and junior high schools are provided school lunches, nutritionally well-balanced diets, at school, which are not included in household expenditure surveys. Most of those, who work away from home, buy their lunch either at workplace-cafeterias or restaurants, which are not included in household expenditure surveys classified by major commodities, rice, meat, vegetables and so on. A radical decline in household expenditures on vegetables by the younger members relative to the older ones in the past decades since the early-1990s may imply distinct reduction of vegetables in at-home con- 
sumption by the Korean young ${ }^{3}$.

This may have caused apparent declines in height growth velocity of South Korean adolescents, statistically observed since the late-1990s, as was the case with their Japanese peers, since the end of the 1970s, which was coincided with the wakamono no kudamono-banare [25] (steering away from fruit by the young) in Japan.

Table 1. Changes in per capita expenditures on vegetables by age, South Korea, presented as percentage of the 50s, 1990 to $2015(50 \mathrm{~s}=100)$.

\begin{tabular}{ccccccc}
\hline age group & $1990-91$ & $1995-96$ & $2000-01$ & $2005-06$ & $2009-10$ & $2015-16$ \\
\hline $0-9$ & 52.4 & 32.2 & 21.9 & 19.4 & 13.3 & 11.8 \\
$10-14$ & 54.4 & 35.2 & 28.5 & 22.5 & 16.2 & 14.2 \\
$15-19$ & 53.8 & 35.6 & 33.6 & 25.9 & 19.6 & 17.2 \\
$20-24$ & 51.0 & 36.3 & 39.7 & 29.7 & 23.2 & 21.7 \\
$25-29$ & 62.7 & 48.9 & 48.5 & 39.3 & 31.3 & 33.4 \\
$30-39$ & 74.9 & 65.4 & 64.0 & 54.0 & 48.6 & 49.0 \\
$40-49$ & 97.0 & 88.2 & 83.4 & 78.0 & 73.9 & 72.3 \\
$50-59$ & 100.0 & 100.0 & 100.0 & 100.0 & 100.0 & 100.0 \\
above 60 & 96.6 & 99.1 & 111.0 & 107.0 & 116.9 & 122.2 \\
supply of & & & & & & $(\mathrm{kg} /$ year $)$ \\
kg/capita & 131.7 & 156.4 & 165.2 & 149.7 & 143.4 & 135.9 \\
\hline
\end{tabular}

Sources: Household Expenditures Surveys, classified by age groups of household head, 1990 to 2016. Per capita expenditures in current won, by age of individual household members are calculated by the author, using TMI model. Net supply per capita, kg, based on KREI, Food Balance Sheets.

Table 2. Changes in per capita expenditures on fruit by age of household members, $\mathrm{S}$. Korea, 1990 to 2016.

\begin{tabular}{ccccccc}
\hline & $1990-91$ & $1995-96$ & $2000-01$ & $2005-06$ & $2010-11$ & $2015-16$ \\
\hline $10-14$ & 55.8 & 42.7 & 45.3 & 45.1 & 42.1 & 33.1 \\
$15-19$ & 55.1 & 42.7 & 47.6 & 43.5 & 36.8 & 35.1 \\
$20-24$ & 56.0 & 45.3 & 50.8 & 46.6 & 33.4 & 35.8 \\
$25-29$ & 67.4 & 60.3 & 61.4 & 60.4 & 45.1 & 46.6 \\
$30-39$ & 75.2 & 72.5 & 71.3 & 71.3 & 64.6 & 64.0 \\
$40-49$ & 90.9 & 88.3 & 87.9 & 83.3 & 86.5 & 83.4 \\
$50-59$ & 100.0 & 100.0 & 100.0 & 100.0 & 100.0 & 100.0 \\
above 60 & 106.3 & 93.3 & 101.5 & 101.5 & 89.0 & 92.7 \\
net supply & & & & & & $(\mathrm{kg} / \mathrm{year})$ \\
kg/capita & 32.5 & 38.0 & 41.3 & 44.7 & 45.5 & 48.8 \\
\hline
\end{tabular}

Sources: the same as for Table 1 . Notes: the same as for Table 1.

${ }^{3}$ In our previous papers [4] [11] [19], which referred to Park, Junghym's cross-sectional analyses of consumption of fruit and vegetables by age groups of the Koreans, based on 1998 and 2001 KNHNES, no conspicuous differences between the young and the old were detected [26]. 
Table 3. Changes in per capita expenditures on all-meat by age groups, S. Korea, with 50 - 59 as base.

\begin{tabular}{ccccc}
\hline age group & $1990-91$ & $2000-01$ & $2010-11$ & $2015-16$ \\
\hline $0-9$ & 52.0 & 49.6 & 46.3 & 46.8 \\
$10-14$ & 52.9 & 52.0 & 50.5 & 48.6 \\
$15-19$ & 49.4 & 50.7 & 48.9 & 47.2 \\
$20-24$ & 46.7 & 50.4 & 42.0 & 42.7 \\
$25-29$ & 61.8 & 59.2 & 50.2 & 53.2 \\
$30-39$ & 74.6 & 73.8 & 63.3 & 69.9 \\
$40-49$ & 95.7 & 93.7 & 96.4 & 93.8 \\
$50-59$ & 100.0 & 100.0 & 100.0 & 100.0 \\
above 60 & 103.6 & 96.1 & 87.9 & 86.5 \\
net supply & & & & $(\mathrm{kg} /$ year $)$ \\
kg/capita & 24.8 & 37.9 & 44.0 & 54.5 \\
\hline
\end{tabular}

Sources: the same as for Table 1 . Notes: the same as for Table 1.

\section{Brief Conclusions}

South Korean high school seniors (boys aged 17) were $2-3 \mathrm{~cm}$ shorter than their Japanese peers in the 1960s through the 1970s. The differences were, however, close to zero by the mid-1990s and South Koreans outgrew Japanese peers by $3 \mathrm{~cm}$ in the mid-2000s. Both countries made remarkably fast economic progress in the post-war era, beginning with South Korea distinctly behind Japan, and converging at the end of the 2010s. In terms of GDP per capita, Japan was still twice as large as South Korea in the mid-2000s, with appreciably more animal proteins in their diets than the latter. Household surveys decomposed into age groups of household members show that younger generations in Japan started to steer away from fruit and vegetables at-home consumption in the mid-1970s.

After converging and surpassing their Japanese peers, male high school seniors in South Korea ceased to grow taller in the mid-2000s and even began to decline slightly in mean height since the early-2010s, with growth velocities from $1^{\text {st }}$ graders in middle school to high school seniors falling steadily as much as 6 $\mathrm{cm}$ from the late-1990s to the early-2010s. When the author decomposed the household expenditure surveys classified by the age groups of household head, he was astonished to discover that children and young adults in South Korea started to steer away from vegetables, not meat, in their household food consumption. In the mid-2010s, children under 20 years of age are estimated to eat less than $15 \%$ of vegetables than the control group of 50-year-olds in the mid-2010s. As the Dutch national diet guidelines recommend, an adequate intake of fruit and vegetables is essential to activate protein intakes in food consumption [27]. 


\section{Acknowledgements}

The author is deeply grateful to Dr. Howard Elliott, former Deputy Director General, ISNAR, The Hague, for affirmative comments and through editing of the manuscript. The author is also dearly appreciative to Mr. Kyungrok Lee, Graduate School in Economics, Korea University, Seoul, for providing time-series data on height of school children by age in the leading districts, South Korea. National data on Household Expenditure Surveys, classified by age groups of household head, 1990 to 2016 were furnished by Dr. Sanghyo Kim, Research Fellow, KREI, a few years ago for the joint research project.

\section{Funding}

No funding received for this study.

\section{Conflicts of Interest}

No conflicts of interest are declared.

\section{References}

[1] Steckel, R.H. (1995) Statue and the Standard of Living. Journal of Economic Literature, 33, 1903-1940.

[2] Federal Reserve Bank of St Louis. Federal Reserve Economic Data.

[3] Kang, H.-Y. (2018) Korea Times.

[4] Mori, H. and Kim, S. (2020) Child Height and Food Consumption in Japan in the Past Century in Comparison with South Korea: Animal Proteins and Other Essential Nutrients. Global Journal of Medical Research, 1, 1-8.

[5] Kim, Y.S. (1982) Growth Status of Korean Children in Japan. Annals of Human Biology, 9, 453-458. https://doi.org/10.1080/03014468200005981

[6] Republic Korea Government, KREI. Food Balance Sheets, Various Issues.

[7] Silventoinen, K. (2003) Determinants of Variation in Adult Body Height. Journal of Biosocial Science, 35, 263-285.

[8] Hatton, T.J. (2013) How Have Europeans Grown So Tall? Oxford Economic Papers, 66, 1-24. https://doi.org/10.1093/oep/gpt030

[9] Grasgruber, P., Sebera, E., Hrazdíra, E., Cacek, J. and Kalina, T. (2016) Major Correlates of Male Height: A Study of 105 Countries. Economics and Human Biology, 21, 172-195. https://doi.org/10.1016/j.ehb.2016.01.005

[10] Grasgruber, P. and Hrazdira, E. (2020) Nutritional and Socio-Economic Predictors of Adult Height in 152 World Populations. Economics \& Human Biology, 37, 1-24. https://doi.org/10.1016/j.ehb.2020.100848

[11] Mori, H. (2020) Structural Changes in Food Consumption and Human Height in East Asia. LAP LAMBERT Academic Publishing, Berlin.

[12] Deaton, A. (2007) Height, Health, and Development. Proceedings of the National Academy of Sciences of the United States of America, 104, 13232-13237. https://doi.org/10.1073/pnas.0611500104

[13] Prentice, A.M., Ward, K.A., Goldberg, G.R., Jarjou, L.M., Moore, S.E., et al. (2013) Critical Windows for Nutritional Interventions against Stunting. The American Journal of Clinical Nutrition, 97, 911-918. https://doi.org/10.3945/ajcn.112.052332 
[14] Cole, T. and Hiroshi, M. (2017) Fifty Years of Child Height in Japan and South Korea: Contrasting Secular Trend Patterns Analyzed by SITAR. American Journal of Human Biology, 30, e23054. https://doi.org/10.1002/ajhb.23054

[15] Japanese Government, Ministry of Health and Welfare. National Nutrition Surveys, Various Issues.

[16] Japanese Government, Ministry of Education. School Health Examination Surveys, Various Issues.

[17] Republic of Korea, Korea Centers for Disease Control and Prevention. Korea National Health and Nutrition Examination Survey, Various Issues.

[18] Republic of Korea, Department of Education. Center for Educational Statistics, Statistical Yearbook of Education, Various Issues.

[19] Mori, H. (2019) Why Did Japanese Children Cease to Grow Taller In Height In The Midst of a Booming Economy in Contrast with South Korean Youth? Annual Bulletin of Social Science, 53, 223-240.

[20] Moon, J.S., et al. (2018) The 2017 Korean National Growth Charts for Children and Adolescents: Development, Improvement and Prospects. Korea Journal of Pediatrics, 61, 135-149. https://doi.org/10.3345/kjp.2018.61.5.135

[21] Japanese Government, Ministry of Education (2018) School Health Examination Survey. Appendix Tables and Figures.

[22] Holmgren, A., et al. (2018) Nordic Populations Are Still Getting Taller-Secular Changes in Height from the $20^{\text {th }}$ Century to $21^{\text {st }}$ Century. Acta Paediatrica, 108, 1311-1320. https://doi.org/10.1111/apa.14683

[23] Mori, H. (2018) Why Koreans Became Taller Than Japanese? Annual Bulletin of Social Science, 52, 177-195.

[24] Republic of Korea, Statistics Korea. Household Expenditure Survey, 1990 to 2016, Courtesy of Dr. Sanghyo Kim, KREI.

[25] Japanese Government, Ministry of Agriculture, Forestry and Fisheries (1995) White Paper on Agriculture 1994, Tokyo.

[26] Park, J.H. (2018) Department of Nutrition, Gachon University, Courtesy.

[27] Peters, S., et al. (2020) Putting Protein Transition into Perspective. Report: A Sustainable and Healthy Diet. Voeding Magazine. 